\title{
The Genetics of Problem and Pathological Gambling: A Systematic Review
}

\author{
Ágoston Gyollai ${ }^{1}$, Mark D. Griffiths ${ }^{2}$, Csaba Barta ${ }^{3}$, Andrea Vereczkei ${ }^{3}$, Róbert Urbán ${ }^{1}$, Bernadette Kun ${ }^{1}$, \\ Gyöngyi Kökönyei ${ }^{1}$, Anna Székely ${ }^{1}$, Mária Sasvári-Székely ${ }^{3}$, Kenneth Blum ${ }^{4,5,6}$ and Zsolt Demetrovics ${ }^{1}{ }^{1}$
}

\begin{abstract}
${ }^{1}$ Institute of Psychology, Eötvös Loránd University, Budapest, Hungary; ${ }^{2}$ Psychology Division, Nottingham Trent University, Nottingham, United Kingdom; ${ }^{3}$ Institute of Medical Chemistry, Molecular Biology and Pathobiochemistry, Semmelweis University, Budapest, Hungary; ${ }^{4}$ Department of Psychiatry, University of Florida College of Medicine, Gainseville, Florida, USA; ${ }^{5}$ Global Integrated Services Unit University of Vermont Center for Clinical \& Translational Science, College of Medicine, Burlington, Vermont, USA; ${ }^{6}$ Dominion Diagnostics, LLC, North Kingstown, Rhode Island, USA
\end{abstract}

\begin{abstract}
Background and aims: The primary aim of the present review was to summarize the findings of genetic studies conducted on problem and pathological gambling. Method: Literature searches were conducted using PubMed, Medline and the HuGE Navigator databases using the keywords 'gambling' and 'genetic*'. Results: The literature searches identified 21 empirical studies that had analyzed data from eight independent samples. Empirical research utilizing twin data accounted for eight of the studies, while gene association data were presented in 13 studies (including one genome wide-association study [GWAS] study). Twin studies emphasized the significant role of genetic and individual environmental factors in problem and pathological gambling. Gene association studies primarily reported the involvement of the dopaminergic and serotonergic systems. Discussion: Despite the relatively low number of genetic studies, the data clearly indicated the genetic vulnerability of problem and pathological gambling. Studies to date have mainly investigated and verified the role of factors reported to be important in other types of addiction, and it is suggested that pathological gambling should be included as a subtype of 'Reward Deficiency Syndrome' (RDS). It is concluded that future research should attempt to identify possible gambling specific susceptibility factors.
\end{abstract}

Keywords: Problem/pathological gambling, gambling addiction, behavioral addiction, systematic review, twin studies, genetic association studies, reward deficiency syndrome.

\section{INTRODUCTION}

Pathological gambling is a chronic, progressive disorder that is often associated with serious financial consequences, loss of employment, substance use, health problems, relationship problems, and criminalization $[1,2]$. Although pathological gambling is still classified among impulse control disorders, it has now been classified as an addiction disorder in the new DSM-V. With this change, gambling disorder is the first behavioral addiction $[3,4]$ to be officially considered an addictive disorder. As with all addictions, pathological gambling disorder is a multi-causal behavior. In addition to the relatively widely researched social and psychological etiological factors, more recent research has emphasized the importance of neurobiological factors. Despite the increase in neurobiological research, the number of studies examining the genetic aspects of pathological gambling is low compared to chemical addictions [5].

There are now well-defined methods available for the analysis of genetic factors. Both twin and adoption studies enable the analysis of the individual and epistatic effects of genetic factors and their interactions with environmental factors. Furthermore, molecular genetic studies do not typically allow for the estimation of the genetic effect in general, but for the identification of one or more specific genetic factors. The aim of the present paper is to provide a systematic review and summary of all the empirical research concerning the genetic background of problem and pathological gambling.

\section{METHOD}

\section{Inclusion and Exclusion Criteria}

The objective of the present study was to review all the empirical literature concerning the genetic aspects of problem and

*Address correspondence to this author at the Eötvös Loránd University, Institute of Psychology, Department of Clinical Psychology and Addiction, Izabella utca 46., H-1064, Budapest, HUNGARY; Tel: +36 3097610 97; Fax: +36 1461 2697; E-mail: demetrovics@t-online.hu pathological gambling that have been published in the English language. Problem gambling is considered as a less severe form of gambling activity when the diagnosis of pathological gambling cannot be confirmed, although a few symptoms of the disorder are already present. As most of the studies deals with problem gambling as well as pathological gambling, it was decided to include both populations in the review. All studies published in English in a scientific journal and that reported empirical results concerning the genetic study of gambling were included in the analysis. Literature searches were carried out in September 2012 with the combination of keywords 'gambling' and 'genetic*' on PubMed and Medline databases. No other filter was applied. The search was also carried out using the HuGE Navigator (http://www.hugenavigator.net) database. As a result of the literature search, 159 papers were found on PubMed, 146 on Medline and 32 on the HuGE database. After the exclusion of duplicates, a total of 185 papers remained for further review and analysis.

\section{Filtering Method}

Papers containing irrelevant content to the aims of the present study $(\mathrm{n}=147)$ were excluded from the analytic review. In these 147 papers, the keyword 'gambling' indicated only an indirect relation and did not actually address gambling. Four other studies were excluded due to linguistic reasons (i.e., the papers were not published in English). Since the primary objective of the present study was to create an overview of all empirical data, a further nine review studies that did not contain any new empirical data were also excluded. One further study [6] was excluded, since it did not reveal any data on the risk for pathological gambling, and only examined the extent to which the genetic and environmental risk for gambling could be explained by the risk for alcohol dependence. Three other studies [7-9] were also excluded for the reason that although they had some relevance to the topic, they did not examine problem gambling behavior per se but assessed neuropsychological tasks with a gambling component on general population partici- 
pants. This filtering process left 21 studies remaining for inclusion and further review.

\section{RESULTS}

\section{Datasets Utilized}

The 21 identified empirical studies analyzed data from eight independent samples. Five twin studies were based on the Vietnam Era Twin Registry (VETR) data, while an additional three datasets were used in three other published studies. Among the studies examining specific genetic factors, five studies published by a Spanish research group analyzed the same dataset, while the four studies published by Comings and his colleagues [10-13] also used various subsamples of one original dataset. Two Brazilian studies also used an identical dataset of 140 participants $[14,15]$. The one remaining study utilized its own distinct dataset.

\section{Types of Data Collected}

The research papers included in the present review broadly comprised two different types of genetic investigations. The first set of research papers $(n=8)$ utilized data from twin studies carried out among four different datasets. These studies utilized samples originating from twin pairs and estimated the effect size of genetic and environmental factors, and their interaction. However, these data are unsuitable in identifying specific genetic factors. The second set of studies $(n=13)$ examined genetic associations in order to analyze the effects of one or more specific genetic factors. Among these 13 papers, one reported a specific type of genetic association study using over 2 million variable markers fairly evenly distributed throughout the entire genome (i.e., a genome wide-association study; GWAS).

\section{Place and Date of Research Study Publication}

Five studies were published in the 1990s (the earliest one being published in 1996) with the remaining 16 studies all published since 2000 . More than half of the studies $(n=11)$ were published by research teams from the United States. Five studies came from research teams in Spain, two from Australia, two from Brazil, and one from Canada.

\section{Results of Twin Studies \\ Samples of Twin Studies}

The published twin studies were carried out on four independent datasets. Of these, the Add Health study [16] is the only one that represents the general population by including children from elementary and secondary schools. Data for the study were first collected in 1994 and 1995. During this time, approximately 90,000 young people were involved in the study. In the first data collection period, a subsample of people living together was created with the participation of 20,740 adolescents and 17,000 parents/primary caregivers. The second round of data collection took place in 1996 and researchers were able to contact 14,738 young individuals successfully. The third round of data collection was carried out during 2001 and 2002 comprising 15,197 people. This sample contained 324 monozygotic (MZ) and 278 dizygotic (DZ) twins [16].

Five studies have been published utilizing data from the Vietnam Era Twin Registry. The entire sample consisted of several thousands of male twins who were engaged in military service during the Vietnam War (1964-1975). This dataset was originally a part of a military records database, but throughout the years it has also become a source for genetic and epidemiologic studies. Different studies utilized different subsamples of this dataset. In the Australian Twin Registry-Cohort, twins were recruited to register by calls from the Australian National Health and Medical Research Council and through the school system between 1980 and 1982. In total, 4,268 pairs of twins (i.e., 8536 people) were born and registered in Australia between 1964 and 1971. The first wave of data collection took place between 1989 and 1992, while the second wave was carried out between 1996 and 2000. During the second wave of the study 4764 people participated. In addition to telephone interviews, respondents also completed questionnaires received by mail [17]. One study carrying out a genetic association study (to be discussed later), also used this dataset [18].

Blanco et al. [19] collected data from 43,799 people using an online survey. The survey was carried out between July 2005 and April 2010. The online tool consisted of personality questionnaires and measures for the assessment of psychopathological data and substance use. The questionnaire was available for all 43,799 to complete. Ultimately, the sample comprised 414 monozygotic and 159 dizygotic twin pairs [20].

\section{Methods Used in Twin Research Studies to Assess Problem and Pathological Gambling}

The studies relating to the Vietnam Era Twin Registry contained problem and pathological gamblers with a diagnosis based on the DSM-III-R or DSM-IV classification system carried out by telephone interview [21-25]. For participants of the Australian Twin Registry Cohort, the NODS (National Opinion Research Center DSM-IV Screen for Gambling Problems) was applied to assess gambling-related problems, and is a tool that utilizes the DSM-IV criteria for pathological gambling [26]. On the Add Health sample, Beaver et al. [16] evaluated gambling-related problems using eight individually developed interview questions. The appropriateness of these applied questions was confirmed afterwards by psychometric analysis. Blanco et al. [19] identified pathological gamblers using the DSM-IV diagnostic criteria. The criteria were initially assessed among those people who previously reported gambling activity at least 24 times in their lifetime. However, fully syndromal DSM-IV PG was rare in this sample, therefore they created a four-category variable termed "symptoms of PG" Categories were: (1) 0-24 lifetime episodes of gambling; (2) $>25$ lifetime episodes of gambling and zero endorsed PG criteria; (3) $>25$ lifetime episodes of gambling and one PG criterion endorsed; (4) $>25$ lifetime episodes of gambling and two or more PG criteria endorsed.

\section{Summary of the Results of Twin Studies}

Based on the results of twin studies, findings indicate that genetic factors contribute significantly to the formation of problem and pathological gambling (see Table 1) irrespective of the definition and tools assessed in the context of problem and pathological gambling. A consistent result of twin studies is that shared environmental factors (e.g., family events, shared friends, shared school experiences, etc.) do not contribute significantly to the formation of gambling problems. However, one exception is the study by Beaver et al. [16] that reported genetic factors failed to explain the variance in gambling for females. Shared environment, however, accounted for $45 \%$ of the variance and the remaining $55 \%$ was attributable to non-shared environmental factors. Alternatively, Slutske et al. [26] highlighted the importance of shared environmental factors (taking the confidence interval ( $\mathrm{CI}=0,0-4,1]$ into account), so environmental factors should not be completely ruled out. Based on studies focusing on comorbid disorders, it appears that problem/pathological gambling and other psychiatric disorders (e.g., major depression [22]) have a partially shared genetic background. According to the findings of Blanco et al. [19], there is only a slight difference in the frequency of gambling between MZ and DZ twins with a moderately lower frequency in the DZ group. Familial resemblance for frequency of gambling resulted both from substantial common environmental effects and (to a slightly lesser degree) from genetic effects. Results of this study show that regarding pathological gambling-related symptoms, the proportion of genetic to individual-specific environmental influence was the same in men and women. 
Table 1. Summary of the findings of twin studies

\begin{tabular}{|c|c|c|c|c|c|c|}
\hline Study & Sample & PG prevalence & $\begin{array}{c}\text { Variance } \\
\text { explained by } \\
\text { genetic factors }\end{array}$ & $\begin{array}{c}\text { Variance explained } \\
\text { by shared } \\
\text { environment }\end{array}$ & $\begin{array}{c}\text { Variance } \\
\text { explained by } \\
\text { non-shared } \\
\text { environment }\end{array}$ & Comorbidity \\
\hline $\begin{array}{l}\text { Slutske et } \\
\text { al. (2001) }\end{array}$ & $\begin{array}{c}\text { VETR }^{1} \\
(\mathrm{~N}=7869)\end{array}$ & $\begin{array}{c}\text { Pathological gambler: } \\
1.4 \% \\
\text { Subclinical pathological } \\
\text { gambler: } 6.4 \% \\
\text { Problem gambler: } 7.8 \%\end{array}$ & $50 \%$ & $0 \%$ & $50 \%$ & $\begin{array}{l}\text { Genetic and non-shared } \\
\text { environmental factors } \\
\text { found in the background } \\
\text { of PG and antisocial } \\
\text { personality disorder } \\
\text { partly overlap. }\end{array}$ \\
\hline $\begin{array}{l}\text { Potenza et } \\
\text { al. (2005) }\end{array}$ & $\begin{array}{c}\text { VETR }^{1} \\
(\mathrm{~N}=7869)\end{array}$ & $\begin{array}{c}\text { Pathological gambler: } \\
1.4 \%\end{array}$ & $66 \%$ & $0 \%$ & $34 \%$ & $\begin{array}{c}\text { PG and major depression } \\
\text { have } 34 \% \text { shared genetic } \\
\text { background. }\end{array}$ \\
\hline $\begin{array}{l}\text { Scherrer et } \\
\text { al. (2005) }\end{array}$ & $\begin{array}{c}\text { VETR }^{1} \\
(\mathrm{~N}=1687)\end{array}$ & $\begin{array}{l}\text { Pathological gambler: } \\
\quad 3.1 \% \\
\text { Problem gambler: } 16 \%\end{array}$ & $\begin{array}{c}\text { no exact } \\
\text { percentage }\end{array}$ & no exact percentage & $\begin{array}{c}\text { no exact } \\
\text { percentage }\end{array}$ & Has not been studied \\
\hline $\begin{array}{l}\text { Beaver et } \\
\text { al. }(2010)\end{array}$ & $\begin{array}{l}\text { Add Health } \\
\quad(\mathrm{N}=602)\end{array}$ & No data available & $\begin{array}{c}72 \% \text { (total sample) } \\
85 \% \text { (only male) } \\
0 \% \text { (only female) }\end{array}$ & $\begin{array}{c}0 \% \text { (total sample) } \\
0 \% \text { (only male) } \\
45 \% \text { (only female) }\end{array}$ & $\begin{array}{c}28 \% \text { (total } \\
\text { sample) } \\
15 \% \text { (only male) } \\
55 \% \text { (only } \\
\text { female) }\end{array}$ & Has not been studied \\
\hline $\begin{array}{l}\text { Slutske et } \\
\text { al. (2010) }\end{array}$ & $\begin{array}{c}\text { ATRC }^{3} \\
(\mathrm{~N}=4764)\end{array}$ & $\begin{array}{c}\text { Pathological gambler: } \\
2.2 \% \text { (total sample); } \\
3.4 \% \text { (only male); } \\
1.2 \% \text { (only female); } \\
\text { Problem gambler: } \\
1.7 \% \text { (total sample); } \\
2.4 \% \text { (only male); } \\
1.1 \% \text { (only female) }\end{array}$ & $\begin{array}{c}49.2 \% \text { (total } \\
\text { sample) } \\
48.5 \% \text { (only male) } \\
51.8 \% \text { (only } \\
\text { female) }\end{array}$ & $0 \%$ & $\begin{array}{c}50.7 \% \text { (total } \\
\text { sample) } \\
51.4 \text { (only male) } \\
48.2 \% \text { (only } \\
\text { female) }\end{array}$ & Has not been studied \\
\hline $\begin{array}{l}\text { Giddens et } \\
\text { al. (2011) }\end{array}$ & $\begin{array}{c}\text { VETR }^{1} \\
(\mathrm{~N}=7869)\end{array}$ & $\begin{array}{c}\text { Pathological gambler: } \\
1.4 \%\end{array}$ & $65 \%$ & no exact percentage & $36 \%$ & $\begin{array}{l}\text { PG and generalized } \\
\text { anxiety disorder have } \\
29 \% ; \text { PG and panic } \\
\text { disorder have } 7 \% \text { shared } \\
\text { genetic background }\end{array}$ \\
\hline $\begin{array}{l}\text { Blanco et } \\
\text { al. (2012) }\end{array}$ & $\mathrm{N}=43799$ & $\begin{array}{c}\text { Disordered gambling } \mathrm{a} \text { : } \\
0.9 \%\end{array}$ & $32 \%^{\mathrm{b}}$ & $42 \%$ & $\begin{array}{c}\text { no exact } \\
\text { percentage }\end{array}$ & $\begin{array}{l}\text { Environmental experi- } \\
\text { ences that increased risk } \\
\text { for disordered gambling } \\
\text { also increased risk for } \\
\text { lifetime major depres- } \\
\text { sion, nicotine depend- } \\
\text { ence and alcohol } \\
\text { consumption, and } \\
\text { modestly decreased the } \\
\text { level of caffeine con- }\end{array}$ \\
\hline
\end{tabular}

${ }^{1}$ VETR: Vietnam Era Twin Registry

sumption.

${ }^{2}$ AddHealth: National Longitudinal Study of Adolescent Health

${ }^{3}$ ATRC: Australian Twin Registry Cohort

${ }^{a}$ Disordered gambling was defined as a four-category variable based on the number of lifetime PG episodes and endorsed PG criteria

${ }^{b}$ Familial resemblance for number of times gambled in twin and sibling pairs 
Table 2. Brief summary of the findings of gene association studies.

\begin{tabular}{|c|c|c|c|c|}
\hline Study & Sample & System & Gene & Result \\
\hline $\begin{array}{l}\text { Pérez de Castro et al. } \\
\text { (1997) }\end{array}$ & $\begin{array}{l}\mathrm{N}=68 \mathrm{PG} \\
68 \text { matched control }\end{array}$ & Dopaminergic & DRD4 48 bp repeat polimorphism & $\begin{array}{l}\text { PG: D4(7)/D4(7) detected only in this } \\
\text { group }\end{array}$ \\
\hline $\begin{array}{l}\text { Comings et al. } \\
\text { (1997) }\end{array}$ & $\begin{array}{l}\mathrm{N}^{1}=127 \mathrm{PG}, 124 \\
\text { control } \\
\mathrm{N}^{2}=186 \mathrm{PG}, 138 \\
\text { control }\end{array}$ & Dopaminergic & $\begin{array}{l}\text { DRD1 Dde I, ANKK1 Taq I } \\
\text { A1/A2 }\end{array}$ & $\begin{array}{l}\text { PG: } 14.1 \% \text { homozygote for DRD1 Dde I } \\
\text { allele ( } \mathrm{p}=0.020) \text {; DRD2 TaqI } 12 \text { group was } \\
\text { carried by } 45.7 \%(\mathrm{p}<0.001) \text {; DRD1 } 11 / 22 \\
\text { and ANKK1 TaqI } 12 \text { genotype was carried } \\
\text { by } 23.3 \%\end{array}$ \\
\hline $\begin{array}{l}\text { Pérez de Castro et al. } \\
\text { (1999) }\end{array}$ & $\begin{array}{l}\mathrm{N}=68 \mathrm{PG} \\
68 \text { matched control }\end{array}$ & Serotonergic & 5-HTTLPR & $\begin{array}{l}\text { PG: short allele version has significantly } \\
\text { higher prevalence in male }(\mathrm{p}=0.02)\end{array}$ \\
\hline $\begin{array}{l}\text { Comings et al. } \\
(2001)\end{array}$ & $\begin{array}{l}\mathrm{N}=139 \mathrm{PG} \\
139 \text { matched control }\end{array}$ & $\begin{array}{l}\text { Dopaminergic } \\
\text { Serotonergic } \\
\text { GABAergic } \\
\text { Other }\end{array}$ & $\begin{array}{l}\text { DRD1,DRD2, DRD3, DRD4, } \\
\text { DRD5, DAT1, SLC6A4, HTR1A, } \\
\text { HTR1DB, HTR2A, HTR2C, } \\
\text { TDO2, TPH, GABRA1, } \\
\text { GABRA3, GABRB1, GABRB3, } \\
\text { NMDAR1, CHRNA4, AR, INFG, } \\
\text { PS1, CRH }\end{array}$ & $\begin{array}{l}\text { PG: significant association with DRD2 } \\
(p<0.001), \text { DRD4 }(p<0.001), \\
\text { DAT1 }(p<0.05), \text { ADRA2C }(p<0.001), \\
\text { TPH }(0.0005) \text { and TDO2 }(p<0.05) \text { genes }\end{array}$ \\
\hline Ibanez et al. (2001) & $\mathrm{N}=69 \mathrm{PG}$ & Dopaminergic & DRD2 & $\begin{array}{l}\text { PG: DRD2 C4 allele has significantly } \\
\text { higher prevalence in lifetime comorbid } \\
\text { disorder }(\mathrm{p}<0.003)\end{array}$ \\
\hline Lobo et al. (2007) & $\begin{array}{l}\mathrm{N}=140 \mathrm{PG}+140 \\
\text { siblings }\end{array}$ & Dopaminergic & $\begin{array}{l}\text { DRD1, DRD2, DRD3,DRD4, } \\
\text { DRD5, SLC6A3 }\end{array}$ & $\begin{array}{l}\text { PG: significant association with DRD1 } 800 \\
T / C \text { allele }(p<0.03)\end{array}$ \\
\hline Lobo et al. (2010) & $\mathrm{N}=242 \mathrm{NPG}$ & Dopaminergic & DRD1, DRD2, DRD3 & $\begin{array}{l}\text { Tendency of lower PGSI scores in } \\
\text { TaqIA/rs } 1800497 \text { polimorphism }(\mathrm{p}=0.10)\end{array}$ \\
\hline Wilson et al. (2012) & $\begin{array}{l}\mathrm{N}=140 \text { (discordant } \\
\text { sib-pairs) }\end{array}$ & Serotonergic & $\begin{array}{l}\text { 44bp, 1B, G861C substitution } \\
\text { polymorphism (5HT-1B G861C), } \\
\text { 2A, T102C exon } 1 \text { substitution }\end{array}$ & $\begin{array}{l}\text { PG: significant association was found with } \\
\text { the } \mathrm{C} \text { allele and the } \mathrm{C} / \mathrm{C} \text { genotype of } 5 \mathrm{HT}- \\
2 \mathrm{~A} \text { T102C }(\mathrm{p}<0.03)\end{array}$ \\
\hline Lind et al. (2012) & $\begin{array}{l}\mathrm{N}=4764 \text { (Australian } \\
\text { Twin Registry } \\
\text { Cohort) }\end{array}$ & $\begin{array}{l}\text { Genome wide } \\
\text { association study }\end{array}$ & $\begin{array}{l}\text { 2,381,914 single nucleotide poly- } \\
\text { morphisms (SNP) }\end{array}$ & $\begin{array}{l}\text { PG: secondary case-control analysis sho- } \\
\text { wed that three SNPs [chromosome } 9 \\
\text { (rs1106076 and rs12305135 near VLDLR) } \\
\text { and rs10812227 near FZD10 on chromo- } \\
\text { some 12)] have significant associations } \\
\text { with the lifetime DSM-IV diagnosis of the } \\
\text { South Oaks Gambling Screen (SOGS (35) } \\
\text { diagnosis. }\end{array}$ \\
\hline
\end{tabular}

$\mathrm{N}^{1}$ : Nr of participants in DRD1 allele analysis $\mathrm{N}^{2}$ : $\mathrm{Nr}$ of participants in DRD2 allele analysis

*PG: Pathological gambler

**NPG: Non-pathological gambler 


\section{RESULTS OF THE GENE ASSOCIATION ANALYSES Samples of the Candidate Gene Studies}

Eight of the 13 studies analyzed datasets consisting of pathological/problem gamblers and adjusted control groups (see Table 2). One study analyzed data from a general population survey [27]. Two studies scanned pairs of siblings where one of them was a problem/pathological gambler [14, 15], and one study investigated gamblers who were participating in a special therapeutic program [28]. For the study examining the entire genome, Lind et al. [18] relied on the Australian Twin Registry-Cohort (discussed above in the section on twin study samples).

\section{Genetic Factors Studied}

Given that the brain reward system is primarily associated with dopaminergic neurotransmission, while impaired behavioral inhibition and impulse control disorder are linked to the serotonergic system [29], it is plausible that the identified studies investigated the polymorphisms of genes linked to these two systems, as well as MAO (monoamine oxidase), that also plays a crucial role in the metabolism of serotonin and dopamine.

\section{Summary of Genetic Findings}

Results of six studies $[10,11,13,14,27,28]$ show a significant association between the dopamine D2 receptor gene (DRD2) and pathological gambling. According to these results, the TaqIA polymorphism of the ANKK1 gene (previously believed to be located within the neighboring DRD2 gene [30]) might have an important role in this association. The results of Ibanez et al. [28] suggest that $\mathrm{C} 4$ allele of DRD2 TG microsatellite polymorphism in intron 2 is associated with the severity of pathological gambling and related lifetime comorbid disorders. Contrary to this, Lobo et al. [27] observed that the ANKK1 TaqIA (rs1800497) polymorphism was associated with lower risk of pathological gambling. Homozygote DdeI and $800 \mathrm{~T} / \mathrm{C}$ alleles of DRD1 also seem to be associated with pathological gambling $[10,14]$ and comorbid alcohol dependence [29]. Three studies show that long alleles (5 to 8 repeat) of the DRD4 gene are associated with pathological gambling [11, 12, 31].

Impulsive behavior and impulse control disorder are also associated with behavioral addictions, therefore specific studies also examined the role of the serotonergic system, which might have a role in pathological gambling-related impulsivity problems [29]. The role of the 5-HTTLPR polymorphism of the serotonin transporter gene has been reported in two studies in male pathological gamblers [32, 33]. Additionally, Wilson et al. [15] found that pathological gambling was significantly associated with the $\mathrm{C}$ allele and $\mathrm{C} / \mathrm{C}$ genotype of 5HT-2A T102C polymorphism.

Among the genes involved in serotonin metabolism, tryptophan hydroxylase (TPH) and tryptophan-2,3-dioxygenase (TDO2) were significantly associated with pathological gambling in the study of Comings et al. [11]. MAO-A has also been found to be associated with pathological gambling $[33,34]$ while MAO-B did not show any connection.

\section{Results of the GWAS Study}

In the study by Lind et al. [18], 2,381,914 single nucleotide polymorphisms (SNP) from the entire genome were examined with methods of family-based association test, gene and pathway enrichment analyses. None of the SNPs have reached the level of genome wide significance, however a $p$-value of less than $1 \times 10^{-5}$ was seen in case of 6 SNPs. These SNPs are located in three genes (i.e., MT1X, ATXN1 and VLDLR), and are assumed to play a role in pathological gambling. A secondary case-control analysis method showed that three SNPs [chromosome 9 (rs1106076 and rs12305135 near VLDLR) and rs10812227 near FZD10 on chromosome 12]] have significant associations with the lifetime DSM-
IV diagnosis of pathological gambling and pathological gambling diagnosis of the South Oaks Gambling Screen (SOGS [35]).

\section{DISCUSSION}

The combined findings of the twin studies presented in this review highlight the complex nature of the problem/pathological gambling phenotype. Based on the results of the studies identified, it is clear that genetic factors (in addition to environmental factors identified elsewhere in the gambling pathology literature) have an important role in the acquisition, development and maintenance of pathological gambling. Additionally, the results of twin study data indicate that the genetic background of gambling problems and comorbid disorders appear to partially overlap. Therefore, further studies are needed to confirm the associative relationships that might help further our understanding of the interaction of these environmental and genetic factors. However, there are also a number of contradictory findings. For instance, while Potenza et al. [22] found that pathological gambling and major depression shared $34 \%$ of their genetic variance, Blanco et al. [19] found a much weaker relationship between the two disorders. However, these contradictory results might be explained by sample selection and differences in diagnostic criteria, bringing the authors to the assumption that the shared genetic variance between the two disorders may increase with the severity of gambling problems [19]. Further empirical examination of shared genetic factors of pathological gambling and comorbid disorders (e.g., depression) thus may help in identifying the common etiological factors. In this regard, focusing on the severity of gambling problems would be especially useful, as it would further the understanding of the possible differences in the background of the initiation, development, and maintenance of gambling problems. Examination of adolescent samples may also be useful in this regard.

The primary finding of the combined genetic association studies indicate the involvement of dopaminergic and serotonergic systems. Such a finding is not surprising given that these two systems are the most often examined neurotransmitters in all types of addiction disorders [36, 37]. In case of dopamine, the role of the brain reward system is most likely to be involved [38], whereas in case of serotonin, the regulation of behavioral inhibition is most likely to be involved [39]. Nevertheless, the available published studies refer exclusively to genetic etiological factors, which are also reported in other types of addictions.

There are, of course, a number of limitations regarding genetic studies of human behavior (including those that have specifically examined gambling outlined here). Most individual studies have a limited sample size, thus restricting statistical power. Replication studies are often incapable of reproducing earlier findings. Furthermore, phenotype heterogeneity makes it difficult to compare studies with each other and to conduct meta-analyses. Applying multiple statistical tests require stringent methods for correction to avoid Type 2 errors. Population stratification can further distort results of these genetic studies.

Although this review has highlighted that genetics can and do play an important role in the development of gambling pathology, other factors (e.g., individual psychological determinants, environmental and situational factors, structural characteristics of the gambling activity itself, etc.) also have important contributory roles. These findings indicate that while genetic predisposition exists, it is likely to be a contributing factor rather than being a parsimonious explanation.

In terms of commonality across all addictive behaviors, including both chemical (e.g., alcohol, nicotine, and other drugs) and behavioral (e.g., pathological gambling, internet addiction, problematic video gaming, sex addiction, food and eating disorders, etc.), Blum et al. [40] coined the term 'Reward Deficiency Syndrome' (RDS) to describe an umbrella nomenclature evoking both common genetic antecedents and environmental factors explaining 
addiction in general as a common phenotypy rather than a singular specific phenotype. In more recent papers by Blum et al. [41, 42] in evaluating two families and five generations, they found that using RDS as a generalized phenotype (that included pathological gambling as well as many other behavioral addictions) there were significant associations with both the DRD2 and the DAT 1 polymorphisms. Specifically, in the genotyped family members, the DRD2 Taq1 A1 and the DAT1 10/10 alleles were statistically significant (at least $p<0.015$ ), and more often found in the RDS families than when compared to controls. The TaqA1 allele occurred in $100 \%$ of Family A individuals $(\mathrm{N}=32)$ and $47.8 \%$ of Family B subjects (11 of 23). In their original paper [40], the authors used Baysian mathematics and found that the predictive value (PV) of carrying only the DRD2 Taq1 A1 resulted in a PV of $74.4 \%$. This suggests that individuals at birth have a high risk of any addictive behavior including pathological gambling in adulthood. This direction of further research, under the concept of 'Reward Deficiency Syndrome', could bring us closer to understanding the common genetic background of different chemical and behavioral addictions. Twin studies [6] also highlight this finding. It would be especially interesting to identify common factors behind the various addictive behaviors but also reveal specific indicators. At the present time it appears that while those in the addictions field have relevant knowledge about a few common factors, not much is known about the indicators that have specific role in the background of a certain addictive disorder.

It would also be useful for future studies to investigate the different categories of gamblers according to the severity of gambling and to analyze whether separate factors can explain the formation of the more (or less) severe gambling careers. To date, very few empirical research studies have been identified examining the genetic background of problem and pathological gambling. It is hoped that further advancement in the gambling studies field will be brought about by (i) changes in DSM-V, (ii) advancement of genetic screening technology, and (iii) collaboration of large consortia resulting in greater sample sizes and statistical power.

\section{CONFLICT OF INTEREST}

The authors confirm that this article content has no conflicts of interest.

\section{ACKNOWLEDGEMENTS}

This work was supported by the Hungarian Scientific Research Fund (grant number 83884). Zsolt Demetrovics and Gyöngyi Kökönyei acknowledge financial support of the János Bolyai Research Fellowship awarded by the Hungarian Academy of Science.

\section{REFERENCES}

[1] Griffiths MD. Betting your life on it: Problem gambling has clear health related consequences. BMJ 2004; 329: 1055-6.

[2] Iancu I, Lowengrub K, Dembinsky Y, Kotler M, Dannon PN. Pathological gambling: an update on neuropathophysiology and pharmacotherapy. CNS Drugs 2008;22: 123-38.

[3] Demetrovics Z, Griffiths MD. Behavioral addictions: Past, present and future. J Behavioral Addictions 2012; 1: 1-2.

[4] Grant JE, Potenza MN, Weinstein A, Gorelick DA. Introduction to behavioral addictions. Am J Drug Alcohol Abuse 2010; 36: 233241.

[5] Potenza MN. Review. The neurobiology of pathological gambling and drug addiction: an overview and new findings. Philos Trans $\mathrm{R}$ Soc Lond B Biol Sci 2008; 363: 3181-9.

[6] Slutske WS, Eisen S, True WR, Lyons MJ, Goldberg J, Tsuang M. Common genetic vulnerability for pathological gambling and alcohol dependence in men. Arch Gen Psychiatry 2000; 57: 66673

[7] Nederhof E, Creemers HE, Huizink AC, Ormel J, Oldehinkel AJ. L-DRD4 genotype not associated with sensation seeking, gambling performance and startle reactivity in adolescents: the TRAILS study. Neuropsychologia 2011; 49: 1359-62.
[8] Eisenegger C, Knoch D, Ebstein RP, Gianotti LR, Sandor PS, Fehr E. Dopamine receptor D4 polymorphism predicts the effect of LDOPA on gambling behavior. Biol Psychiatry 2010; 67: 702-6.

[9] Juhasz G, Downey D, Hinvest N, et al. Risk-taking behavior in a gambling task associated with variations in the tryptophan hydroxylase 2 gene: relevance to psychiatric disorders. Neuropsychopharmacology 2010; 35: 1109-19.

[10] Comings DE, Gade R, Wu S, et al.Studies of the potential role of the dopamine D1 receptor gene in addictive behaviors. Mol Psychiatry $1997 ; 2: 44-56$.

[11] Comings DE, Gade-Andavolu R, et al. The additive effect of neurotransmitter genes in pathological gambling. Clin Genet 2001; 60: 107-16.

[12] Comings DE, Gonzalez N, Wu S, et al. Studies of the 48 bp repeat polymorphism of the DRD4 gene in impulsive, compulsive, addictive behaviors: Tourette syndrome, ADHD, pathological gambling, and substance abuse. Am J Med Genet 1999; 88: 358-68.

[13] Comings DE, Rosenthal RJ, Lesieur HR, et al. A study of the dopamine D2 receptor gene in pathological gambling. Pharmacogenetics 1996; 6: 223-34.

[14] Lobo DS, Vallada HP, Knight J, et al. Dopamine genes and pathological gambling in discordant sib-pairs. J Gambl Stud 2007; 23: 421-3.

[15] Wilson D, Lobo DS, Tavares H, Gentil V, Vallada H. FamilyBased Association Analysis of Serotonin Genes in Pathological Gambling Disorder: Evidence of Vulnerability Risk in the 5HT-2A Receptor Gene. J Mol Neurosci 2012.

[16] Beaver KM, Hoffman T, Shields RT. Gender differences in genetic and environmental influences on gambling: results from a sample of twins from the National Longitudinal Study of Adolescent Health. Addiction 2010; 105: 536-42.

[17] Slutske WS, Meier MH, Zhu G, Statham DJ, Blaszczynski A, Martin NG. The Australian Twin Study of Gambling (OZ-GAM): rationale, sample description, predictors of participation, and a first look at sources of individual differences in gambling involvement. Twin Res Hum Genet 2009; 12: 63-78.

[18] Lind PA, Zhu G, Montgomery GW, et al. Genome-wide association study of a quantitative disordered gambling trait Addict Biol 2012

[19] Blanco C, Myers J, Kendler KS. Gambling, disordered gambling and their association with major depression and substance use: web-based cohort and twin-sibling study. Psychol Med 2012; 42: 497-508.

[20] Kendler KS, Prescott CA (2006): Genes, environment, an psychopathology: Understanding the causes of psychiatric and substance use disorders. New York: Guilford.

[21] Giddens JL, Xian H, Scherrer JF, Eisen SA, Potenza MN. Shared genetic contributions to anxiety disorders and pathological gambling in a male population. J Affect Disord 2011; 132: 406-12.

[22] Potenza MN, Xian H, Shah K, Scherrer JF, Eisen SA. Shared genetic contributions to pathological gambling and major depression in men. Arch Gen Psychiatry 2005; 62: 1015-21.

[23] Scherrer JF, Xian H, Shah KR, Volberg R, Slutske W, Eisen SA. Effect of genes, environment, and lifetime co-occurring disorders on health-related quality of life in problem and pathological gamblers. Arch Gen Psychiatry 2005; 62: 677-83.

[24] Slutske WS, Eisen S, Xian H, et al. A twin study of the association between pathological gambling and antisocial personality disorder. J Abnorm Psychol 2001; 110: 297-308.

[25] Xian H, Scherrer JF, Slutske WS, Shah KR, Volberg R, Eisen SA. Genetic and environmental contributions to pathological gambling symptoms in a 10-year follow-up. Twin Res Hum Genet 2007; 10: 174-9.

[26] Slutske WS, Zhu G, Meier MH, Martin NG. Genetic and environmental influences on disordered gambling in men and women. Arch Gen Psychiatry 2010; 67: 624-630.

[27] Lobo DS, Souza RP, Tong RP, et al. Association of functional variants in the dopamine D2-like receptors with risk for gambling behaviour in healthy Caucasian subjects. Biol Psychol 2010; 85: 33-7.

[28] Ibanez A, Blanco C, Donahue E, et al. Psychiatric comorbidity in pathological gamblers seeking treatment. Am J Psychiatry 2001; 158: $1733-5$.

[29] Lobo DS, Kennedy JL. Genetic aspects of pathological gambling: a complex disorder with shared genetic vulnerabilities. Addiction 2009; 104: 1454-65. 
[30] Neville MJ, Johnstone EC, Walton RT. Identification and characterization of ANKK1: a novel kinase gene closely linked to DRD2 on chromosome band 11q23.1. Hum Mutat 2004; 23: 540-5.

[31] Perez de Castro I, Ibanez A, Torres P, Saiz-Ruiz J, FernandezPiqueras J. Genetic association study between pathological gambling and a functional DNA polymorphism at the D4 receptor gene. Pharmacogenetics 1997; 7: 345-8.

[32] Perez de Castro I, Ibanez A, Saiz-Ruiz J, Fernandez-Piqueras J. Genetic contribution to pathological gambling: possible association between a functional DNA polymorphism at the serotonin transporter gene (5-HTT) and affected men. Pharmacogenetics 1999; : 397-400

[33] Perez de Castro I, Ibanez A, Saiz-Ruiz J, Fernandez-Piqueras J. Concurrent positive association between pathological gambling and functional DNA polymorphisms at the MAO-A and the 5-HT transporter genes. Mol Psychiatry 2002; 7: 927-8.

[34] Ibanez A, Perez de Castro I, Fernandez-Piqueras J, Blanco C, SaizRuiz J. Pathological gambling and DNA polymorphic markers at MAO-A and MAO-B genes. Mol Psychiatry 2000; 5: 105-9.

[35] Lesieur HR, Blume SB. The South Oaks Gambling Screen (SOGS): a new instrument for the identification of pathological gamblers. Am J Psychiatry 1987; 144: 1184-8.

Received: July 15, 2013

Accepted: August 26, 2013
[36] Agrawal A, Verweij KJ, Gillespie NA, et al. The genetics of addiction-a translational perspective. Transl Psychiatry 2012; 2: e140.

[37] Brewer JA, Potenza MN. The neurobiology and genetics of impulse control disorders: relationships to drug addictions. Biochem Pharmacol 2008; 75: 63-75.

[38] Le Foll B, Gallo A, Le Strat Y, Lu L, Gorwood P. Genetics of dopamine receptors and drug addiction: a comprehensive review. Behav Pharmacol 2009; 20: 1-17.

[39] Kirby LG, Zeeb FD, Winstanley CA. Contributions of serotonin in addiction vulnerability. Neuropharmacology 2011; 61: 421-32.

[40] Blum K, Sheridan PJ, Wood RC, et al. The D2 dopamine receptor gene as a determinant of reward deficiency syndrome. J R Soc Med 1996; 89: 396-400.

[41] Blum K, Chen AL, Oscar-Berman M, et al. Generational association studies of dopaminergic genes in reward deficiency syndrome (RDS) subjects: selecting appropriate phenotypes for reward dependence behaviors. Int J Environ Res Public Health 2011; 8: 4425-59.

[42] Blum K, Oscar-Berman M, Bowirrat A, et al. Neuropsychiatric Genetics of Happiness, Friendships, and Politics: Hypothesizing Homophily ("Birds of a Feather Flock Together") as a Function of Reward Gene Polymorphisms. J Genet Syndr Gene Ther 3. 2012. 